Marquette University

e-Publications@Marquette

Social and Cultural Sciences Faculty Research and

Publications

Social and Cultural Sciences, Department of

$1-1-2005$

\title{
Targeting Arab/Muslim/South Asian Americans: Criminalization and Cultural Citizenship
}

Louise Cainkar

Marquette University, Louise.Cainkar@mu.edu

Sunaina Maira

University of California - Davis

Published version. Amerasia Journal, Vol. 31, No. 3 (2005): 1-28. Publisher link. (C) 2005 University of California Press. Used with permission.

Louise Cainkar was affiliated with the University of Illinois at Chicago at time of publication. 


\section{Targeting Arab/Muslim/ South Asian Americans: Criminalization and Cultural Citizenship}

\section{Louise Cainkar and Sunaina Maira}

\section{Introduction}

Arabs, Muslims, and South Asians have been the primary targets of the U.S. government's global War on Terror since the September 11, 2001 attacks. ${ }^{1}$ Those who live in the United States are no exception. They have been subjected to extensive "security" measures since the attacks, their rights undermined if not revoked by new policies, hastily passed legislation, and selective law enforcement. ${ }^{2}$ They have been portrayed in the mainstream media and by a number of U.S. government officials as citizen-suspects who lie outside American cultural norms, and as communities that harbor "sleeping" terrorists, posing a threat to the nation's security. In this essay, we focus on how Arabs, Muslims, and South Asians have been framed and targeted through a process of criminalization that represents them as members of a deviant group whose belief system is distinctly "foreign" and opposed to core American values. Members of this group are presumed to inherently support criminal actions defined as "terrorist" activity. We argue that the ideological process of criminalization leads to the exclusion of Arab and South Asian Muslim Americans from full national belonging, or cultural citizenship.

In this essay, we further explore the responses of Arab and South Asian Muslim communities to the War on Terror, and ask

LOUISE CAINKAR is a sociologist and ethnographer and Senior Research Fellow at the University of Illinois at Chicago, Great Cities Institute. Currently she is a visiting professor at the University of Michigan, Ann Arbor, teaching classes on Muslims in the U.S. after 9/11 and Arab American history.

Sunaina Maira is an associate professor of Asian American Studies and the author of a forthcoming book on South Asian Muslim youth in the U.S. after $9 / 11$, citizenship, and empire. 
whether these responses reveal alliance-building and pan-ethnic identification. Do the targeted groups, now portrayed as monolithic, find solidarity with each other, and if so, what are the bases for their sense of affinity? These questions force us to consider deeper issues of pan-ethnic and political affiliation that highlight quandaries at the core of Asian American studies: how does a pan-ethnic approach challenge or support the racial and cultural categories used by state and empire to subordinate and divide populations? Are there fruitful linkages that can be made between Asian American and Arab American studies that could illuminate these processes of social classification and shed light on geographic, national, and racial boundaries? Such questions are central to the vision and purpose of Asian American and Arab American studies. We seek to draw attention to common experiences between the subjects of Asian American and Arab American studies to provide a critique of the conventional boundaries established by ethnic and area studies, to uncover their link to state policies, and to bring forth a more radical vision for our intellectual work in the post-9/11 moment.

\section{Criminalization and Cultural Citizenship}

Our argument hinges on the use of two major analytic concepts, criminalization and cultural citizenship, and their relationship to each other, to explain the targeting of Arabs, South Asians, and Muslims in the U.S. after $9 / 11$. We define criminalization as a process by which the state creates and enforces penalties for actions that it claims violate public safety. Our critique of criminalization centers on state policies objectively unrelated to actual public harm and on selective enforcement of laws so that particular groups are penalized, but not others. Criminalization is often discussed in relation to sweeps, as when police "sweep" certain areas of homeless persons before major events, ${ }^{3}$ or "sweep" youth preemptively off street corners, and clearances, through which authorities "clear" members of targeted groups to carry on with daily life activities, a process expressed in the term "driving while Black." Criminalized groups are often tracked and monitored. While the state attempts to legitimate these policies by claiming that the groups targeted are a public safety threat, in practice, their implementation reveals more than anything the powerlessness of the targeted groups. The War on Crime, the War on Drugs, and now the War on Terror share these features of criminalization processes. ${ }^{4}$ Features of the domestic War on 
Terror that criminalize the innocent through sweeps, clearances, and monitoring, include dragnet arrests, undercover activities at mosques, and Special Registration of Muslim men.

Criminalization and cultural citizenship are related as they are both embedded in power relations and in processes of disciplining subjects by the state through law, policy, and cultural and social categorizations. Cultural citizenship is defined as the everyday experience of belonging to the nation-state in relation to experiences of inclusion and exclusion. Citizenship has traditionally been thought of in political, economic, and civic terms, ${ }^{5}$ but more recent analyses focus on the notion of cultural citizenship. As multiethnic societies are forced to confront questions of difference that undergird social inequality, it has become clear that the rights and obligations of legal citizenship are mediated by race, ethnicity, gender, and sexuality, as well as religion. These social locations-as much or more than legal citizenship-affect the extent to which a group feels and acts like a member of the nation-state in which it resides. ${ }^{6}$ Cultural citizenship, according to anthropologist Lok Siu, consists of the "behaviors, discourses, and practices that give meaning to citizenship as lived experience" in the context of "an uneven and complex field of structural inequalities," the "quotidian practices of inclusion and exclusion."7

Latino studies scholars Renato Rosaldo, William Flores, and Rina Benmayor developed the concept of cultural citizenship to connect the cultural and civil rights of immigrants to new social movements. ${ }^{8}$ Their approach to cultural citizenship analyzes "how cultural phenomena-from practices that organize the daily life of individuals, families, and the community, to linguistic and artistic expression-cross the political realm and contribute to the process of affirming and building an emerging Latino identity and political and social consciousness." ${ }^{\prime 9}$ Others, such as Aihwa Ong, are concerned with the process by which the state regulates individual behaviors and beliefs about national belonging. Ong defines cultural citizenship as "a dual process of self-making and being-made within webs of power linked to the nation-state and: civil society." 10

Cultural citizenship is linked to the process of criminalization because the precursor and outcome of group criminalization is cultural and political exclusion from the nation-state. Arab and South Asian Muslims in the U.S. have been denied their rights not only by official state policies, but also by representations that have construed these groups as outside the bounds of U.S. cul- 
tural citizenship. Groups with political power lie inside the cultural norm of national belonging and have the power to prevent policy-making that would criminalize themselves. Cultural representations of Arabs and Muslims, in particular, draw on distinctions between a presumably superior "Western" civilization and an exotic and supposedly barbaric "Muslim world." These ideas justify discriminatory state policies as well as U.S. military interventions in a broadly defined Middle East, the geographies of the "clash between civilizations." Arabs and Muslims in the West are portrayed in this Orientalist worldview as inherently foreign, essentially unassimilable, and a potential enemy within. ${ }^{11}$

Why have Arab and South Asian Muslims in the United States been selected for criminalization by state policies and exclusion from cultural citizenship? We argue that the U.S. government has targeted these groups both before and after $9 / 11$ because of its particular political interests in the regions from which these comimunities originate. The criminalization of these groups is linked to the rise of the U.S. as a global power and to silencing dissent of its foreign policy objectives. Since $9 / 11$, they have provided an internal and external scapegoat for the nation's foreign policy failures, the perceived sense of vulnerability of its inhabitants, and its inability to protect its citizens. Excluding Arab and South Asian Muslims from cultural citizenship and criminalizing their communities is the ideological and practical work that builds popular support for sacrificing their civil rights for the presumed sense of safety of the majority, links them to "enemy" nations and combatants, and delegitimizes their dissent. Isolated as potentially disloyal, in part using notions of essential cultural difference that are diffused through the mainstream media and in popular culture representations, the profiling and criminalization of these groups by the state is tolerated by the public. Arabs, Muslim, and South Asian Americans become accepted as cultural outsiders, so that what happens to them is (falsely) seen as not affecting anyone else. In the process, the state whittles away one democratic right after another, so that prolonged and secret detentions, detention without charge, and even torture of detainees become acceptable state practices in the name of "national security."

Before $9 / 11$, about 80 percent of the American public thought it was wrong for law enforcement to use racial profiling, a term popularly used to refer to the disproportionate targeting of Af- 
rican American drivers by police. After the shock of the $9 / 11$ attacks, a majority of the American public favored racial profiling, "at least as long as it was directed at Arabs and Muslims." Many also believed it was better to limit the presence of Arabs and Muslims in the United States. A March 2002 CNN/Gallup/ USA Today poll found that nearly 60 percent of Americans favored reducing the number of Muslim immigrants admitted to the United States. ${ }^{13}$ Negative and racist media portrayals of Arabs and South Asian Muslims lent ongoing support to domestic and global state policies so that an October, 2002 ABC News/Beliefnet poll found that the proportion of American adults holding an unfavorable view of Islam had risen from 24 percent to 33 percent in the nine months from January to October 2002. ${ }^{14}$ As recently as December 2004, Cornell University found that nearly 50 percent of respondents in a national poll believed the U.S. government should curtail civil liberties for Muslim Americans. ${ }^{15}$ The racial profiling of Muslims, Arabs, and South Asians by the state is akin to a form of Green McCarthyism, as Vijay Prashad points out, and is not just a version of the common, domestic form of racial profiling. While the notion of race has always been an ambiguous social construct in the U.S., it is also true that domestic racialization policies have been linked to the state's international policies, in addition to its domestic agendas. ${ }^{16}$

Arab American communities have endured racial profiling by the state for years, because of U.S. foreign policies in the Arab world, specifically tied to U.S. support of the Israeli occupation of Palestine. Well before 9/11, Arab Americans experienced special legislation and policing actions aimed at pro-Palestinian political activists whose main outcome has been to stifle their voices in American political debate. ${ }^{17}$ Nonviolent activists have been spied on and threatened with deportation, including naturalized U.S. citizens. As was characteristic of state-sponsored repression during the McCarthy era and Hoover's FBI, lawful challenges to U.S. policies (this time related to the Middle East) became an obsessive target of U.S. intelligence agencies. For such instances; see the documentation of Operation Boulder and the Los Angeles 8 case. ${ }^{18}$ Consecutive pieces of anti-terrorism legislation that replaced anti-communist laws with laws that mainly targeted Arabs, and the historic exclusion of Arabs from political campaigns, including the return of Arab-American campaign donations, have assured a silenced Arab American community in which many are fearful of expressing dissent. ${ }^{19}$ 


\section{Post-9/11 Policies of Criminalization}

The U.S. government implemented a broad range of administrative, legislative, and judicial measures in the name of national security and the War on Terror after the attacks of September 11, with little public debate. Among these were: mass arrests, secret and indefinite detentions, prolonged detention of "material witnesses," closed hearings, secret evidence, eavesdropping on attorney-client conversations, FBI home and work visits, wiretapping, property seizures, selective removals of aliens with technical visa violations, and mandatory Special Registration. At least 100,000 Arabs and South Asian Muslims living in the United States have personally experienced one of these measures. ${ }^{20}$ Twenty-five of the thirty-seven known U.S. government security initiatives implemented in the eighteen months after the September 11 attacks explicitly or implicitly targeted Arabs and South Asian Muslims in the United States. ${ }^{21}$ This legal and political context has been augmented by sensationalized media portrayals of Muslims, strong anti-Muslim/anti-Islamic rhetoric from the political right, and continued public backlash, evidenced in hate crimes, hate speech, and job discrimination. Arab and South Asian Muslims report being marginalized as "the other" in American society by policies that have singled them out as a group that is dangerous and potentially subversive; they express serious concerns about their civil rights and safety under these conditions. ${ }^{22}$

The U.S. Congress diminished the civil rights of all Americans when it hastily passed the USA Patriot Act (Uniting and Strengthening America by Providing Appropriate Tools Required to Intercept and Obstruct Terrorism Act of 2001), crafted by the executive branch, in October 2001.23 The USA Patriot Act expands the power of the U.S. government to use surveillance and wiretapping without first showing probable cause, permits secret searches and access to private records by government agents without oversight, authorizes the detention of immigrants on alleged suspicions, denies admission to the United States because of a person's speech, and expands the concept of guilt by association, among other erosions of basic civil rights. The overwhelming majority of known uses of these powers have been exercised on Arab and South Asian Muslims in the U.S. Comparing the government's response to the September 11 attacks to the 1919 Palmer Raids, World War II internment of persons of Japanese descent, and Cold War McCarthyism, legal scholar David Cole identifies the targeting of immigrants and vulnerable groups; 


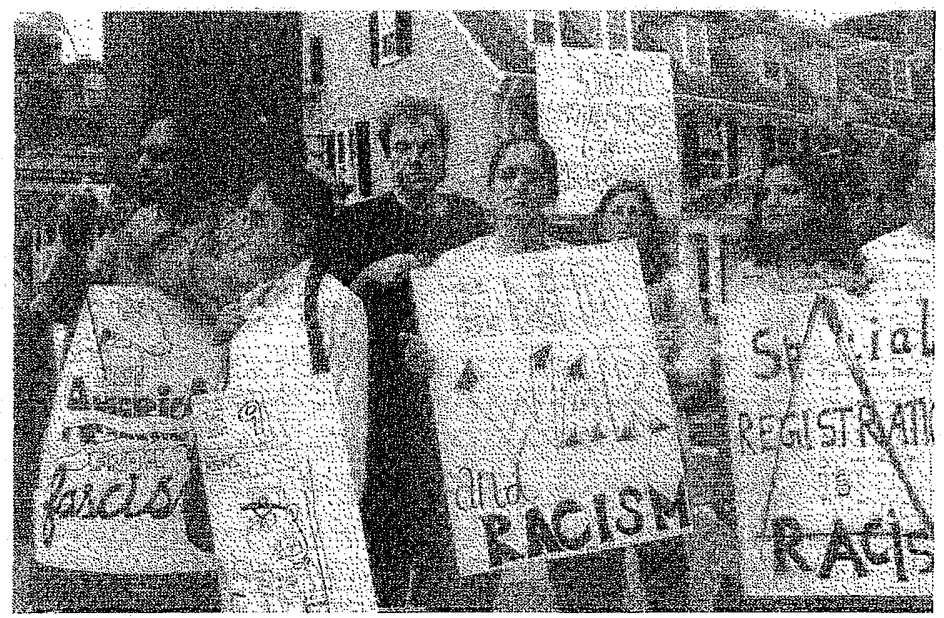

Cambridge rally by a coaltion of organizations, including South Asian Committee on Human Rights, to oppose Special Registration for Muslim males, August 2, 2003.

Photograph by Louise Cainkar

focus on political speech, political activity, and group identity; and reliance on broad sweeps instead of focused, objective investigations into the behavior of individuals as common elements. These types of sweeping measures have in the past led to "misguided enforcement directed at political dissidents rather than crimrinals." ${ }^{24}$

Immediately after the $9 / 11$ attacks, some 1,200 citizens and non-citizens, almost exclusively Arab and South Asian Muslim males, were swept up and detained under high security conditions. ${ }^{25}$ Their identities are largely unknown because the federal government has not released this information. More than 500 were picked up for technical visa violations and eventually deported after being cleared of terrorist connections. ${ }^{26}$ Special security checks and removal from airplanes were implemented for Arab and South Asian men presumed to be Muslims traveling through U.S. airports. "Flying while Arab" was the title of a piece in the February 2002 issue of Arab-American Business Magazine, describing these experiences as the airborne equivalent of "driving while Black." While the mass arrests and airline profiling started decreasing in mid-2002, Arabs and South Asian Muslims have continued to feel under siege because of ongoing home and business raids, FBI interviews, spying, and wiretapping, fear over the criminalization of charitable donations, and 
banking policies that have forced closure of some of their private and business accounts. ${ }^{27}$

The federal government's actions since $9 / 11$ have led the American civil rights community to protest that it has overstepped its legitimate porver in its mission to secure the U.S. and its borders. ${ }^{28}$ Legal experts point out that the state has engaged in measures that are "unnecessary, unconstitutional, and counterproductive." 29 Many question whether selling "a vulnerable minority's rights ... in the name of security" has made the country safer, let alone whether this is even morally justifiable for a presumably democratic society. ${ }^{30}$ The national security benefit of all these measures is highly questionable. An analysis of the outcomes of more than 300 terrorism-related cases completed since $9 / 11$ shows a pattern of plea-bargained convictions on charges unrelated to terrorism. ${ }^{31}$ When removal (deportation) is easier than proving a case, as in the case of non-citizens, the government has often taken the former option.

\section{Special Registration: A Policy of Tracking and Removal}

One selectively enforced and discriminatory federal policy is the U.S. government's "Special Registration" program. On September 11, 2002, the Immigration and Naturalization Service (INS), then part of the Department of Justice, implemented this tracking and clearance program, requiring "certain non-immigrant aliens" to register with the U.S. immigration authorities, be fingerprinted and photographed, respond to questioning, and submit to regular reporting. ${ }^{32}$ The targeted aliens were male visitors aged 16-64 from twenty-three Muslim-majority countries in Asia and the Arab world, plus heavily Muslim Eritrea and North Korea. Special Registration was required of persons already in the United States and those newly entering the country. The program's stated purpose was to facilitate the "monitoring" of these aliens "in the interest of national security." ${ }^{33}$ INS fliers had THIS NOTICE IS FOR YOU splayed across the top, suggestive of the callin notices posted for Japanese Americans living in the Western United States during World War II.

According to the Department of Homeland Security, 82,880 persons living in the United States had been "specially" registered by June 1, 2003 through call-in registration. Of these men who willingly complied with the state's monitoring program, 13,434 were placed in removal (deportation) proceedings for visa 
violations, after they were cleared of connections to terrorism..$^{34}$ Another 127,694 persons were registered at their U.S. Port of Entry. ${ }^{35}$ Out of more than 200,000 persons registered by Special Registration, only eleven were charged with security-related offenses, cases for which the outcome is not yet known.

The arrest and detention of some 800 voluntary registrants during the first phase of the program in Southern California sparked nationwide protest. Persons seeking to comply with the rules were handcuffed and led off to jail for visa violations; some reported verbal abuse and body cavity searches. Detainees were forced to sleep on concrete floors, in group holding cells. Most of these early detainees from Special Registration were Iranian professionals and their family members who had not returned to Iran after the Islamic revolution. They were working taxpayers with families who had otherwise lived lawfully (except for visa status issues) in the United States for decades. Quite a few had pending applications for permanent residency. ${ }^{36}$ Aware that their visa status was problematic, they registered to demonstrate their law abidance and lack of culpability for any acts of terror. Their keepers, however, had only the homogenized image of the guilty Muslim in their minds. Eventually, most of these detainees were released on bail and placed in removal (deportation) proceedings by the INS. The relatively affluent class position and organized nature of the Iranian American community in Los Angeles enabled them to draw attention to their plight by launching a successful and speedy media campaign and string of protests around the country. The director of the Southern California chapter of the American Civil Liberties Union (ACLU) said the arrests were "reminiscent of the internment of Japanese Americans during World War II." ${ }^{37}$

The Special Registration program was a massive round up of out-of-status Arabs, Asians, and North Africans from predominantly Muslim countries with few historical precedents in its scale. ${ }^{33}$ It used the selective enforcement of immigration laws to target members of these groups for deportation, although they comprised less than one percent of the estimated three million persons who were "out of status" and the eight million undocumented in the United States. ${ }^{39}$ In addition, tens of thousands of Arabs and South Asians fled the United States rather than submit to Special Registration's tracking mechanisms. In Chicago, New York, and other cities, Pakistani neighborhoods and businesses appeared to be vacated almost overnight. Some families fled to the 
Canadian border seeking political asylum.

After stating for months that the Special Registration program was not discriminatory because it would be eventually expanded to include all visiting aliens, the U.S. government announced the program's phase out in May 2003. Government authorities never clearly explained why persons from these twenty-five countries were selected for the Special Registration program. At times, the government stated that the countries whose citizens and nationals were required to register were selected because of the presence of Al Qaeda, although countries with no known Al Qaeda presence were included and countries with a proven Al Qneda presence, such as Germany and England, were excluded. Broader Bush administration programs to monitor Muslims who are U.S. citizens include then FBI Director Robert Mueller's initiative to base FBI goals for wire-tapping and undercover activities on the number of mosques in an area. ${ }^{40}$

Because the Special Registration program targeted persons by their country of birth, it shares features of the family of U.S. policies based on ideas about race (beginning with slavery and Indian removal), such as the 1790 Naturalization Law, which denied naturalized citizenship to non-whites (repealed in 1952); the 1882 Chinese Exclusion Act (repealed in 1943); the Asia Barred Zone (enacted in 1917 and revoked in 1952); and immigration quotas (enacted in 1921, revised in 1924 and ended in 1965). When immigration quotas were abolished in 1965, it signaled the end of an era in which U.S. immigration policies were based principally on race. Thereafter, it was considered against liberal democratic principles to blatantly discriminate by country of birth. In 1981, however, permission to regulate persons from certain "foreign states" re-emerged in immigration legislation, allowing the attorney general to require "natives of any one or more foreign states, or any class of group thereof" to provide an address and other information upon ten days notice. The Iran crisis of 1980 was specifically mentioned in the House Judiciary Committee report submitted for the 1981 law, which stated, "immediate access to records of non-immigrants may be vital to our nation's security." ${ }^{\prime 1}$ Thus, the authority to implement selective immigration procedures tied to country of birth was linked to U.S. strategic interests in the Middle East even before 9/11, and is tied to American concerns about Islamist movements and the Iranian revolution. Attorney General Ashcroft used this 1981 law, as well as precedents dating back to the 1790 Aliens and Seditions Acts, to 
- authorize the domestic Special Registration. ${ }^{42}$

Even prior toSpecial Registration, more Arabs and South Asian Muslims (none accused of terrorist connections) had been removed from the United States as a consequence of the September 11 attacks than the number of foreign nationals deported for their political beliefs following the infamous 1919 Palmer Raids. The Department of Justice Inspector General's report confirmed at least 565 persons removed for visa violations from among those swept up immediately after the $9 / 11$ attacks. ${ }^{43}$

\section{Hate Crimes: Indicators of Ideological Penetration in Popular Culture}

Public backlash against suspect members of Arab and South Asian Muslim communities, who lie outside the parameters of cultural citizenship, manifests itself in hate crimes, hate speech, and job discrimination. In the first seven days following September 11, 2001, Arabs and South Asians reported 645 "bias incidents and hate crimes" to the Council on American-Islamic Relations (CAIR)." At end of six months, the figure rose to 1717 , then declined to 325 reported incidents in the second six-month period. ${ }^{45}$ CAIR characterized the post $9 / 11$ anti-Muslim attacks as more violent than those of prior years, indicating they were not a new phenomenon, and noted that they included a number of murders. In 2002, CAIR noted increasing reports of discrimination, especially in the workplace and by government agents conducting raids, interrogations, searches, and property seizures; by 2003 reports of these incidents and hate crimes had increased 70 percent over 2002.46 In Chicago, more than 100 hate crimes against Arabs and South Asian Muslims, as well as persons mistaken for them, were reported to the Chicago Commission on Human Relations by the end of December 2001. ${ }^{47}$ In addition, several Arab and South Asian Muslim institutions were attacked. On September 12, 2001, a mob of hundreds of angry whites, some shouting, "kill the Arabs" and wielding weapons, commenced a march to the largest, predominantly Arab mosque in Chicagoland..$^{43} \mathrm{~A}$. predominantly South Asian and Arab mosque in suburban Villa Park was vandalized in the spring of 2003, and attempts to build two new suburban mosques met with strong community opposition in $2004 .{ }^{49}$

In the months immediately following the September 11 attacks, Muslim women in Chicago repeatedly reported having their head scarves yanked off or being spit at on the street. ${ }^{50}$ These inci- 
dents still occur, although with less frequency, and fear still exists within local Arab and Muslim communities. Similar strikes on Muslim women have occurred nationally. For example, on October 5, 2003, a Muslim woman wearing a lijab (head scarf) was attacked in a K-Mart parking lot in Springfield, Virginia. The white male teenage attacker allegedly shouted, "you terrorist pig," before running away. Many community leaders blame the U.S. government's sweeping and unfocused actions in their communities, and the media's sensational coverage of the "war on terrorism," for encouraging anti-Arab and anti-Muslim sentiment. Arab and South Asian Muslim concerns remain about profiling, intolerance, and the long-term effects of discrimination. ${ }^{51}$

\section{Islamophobia}

Islamophobia is a persistent strain of essentialist ideologies that criminalize Arabs, South Asians, and Muslims by claiming that these groups deviate from normative cultural citizenship and pose a threat to the nation. ${ }^{52} \mathrm{As}^{\prime}$ ad AbuKhalil points out that embedded in these anti-Muslim views is the phenomenon of "theologocentrism," by which anti-Muslim scholars and politicians explain all political behaviors of Muslims or Arabs by reference to the Quran..$^{53}$ Neoconservative and Christian right spokespersons routinely express displeasure with the idea of American society embracing Muslims. They describe Islam as a religion outside the pale of human values and some have labeled Muslims as "worse than Nazis." ${ }^{15}$ Evangelists Lind and Weyrich, in a booklet titled Why Islam is a Tlireat to America and the West, argue that Muslims "should be encouraged to leave. They are a fifth column in this country." 55

\section{Community Impact of State Policies}

In order to show the ways in which state policies have affected specific communities of Arabs, South Asians, and Muslims we briefly examine two urban areas, Chicago and Cambridge/Boston. It is interesting to juxtapose findings from South Asian, Arab, and Muslim communities in these two locales, which have been discussed much less than New York in the context of post-9/11 issues, and which have their own political, ethnic, and religious landscapes. We focus on the experiences of women in Chicago and youth in the Boston area, building on our own research expertise, in order to shed light on the ways in which post-9/11 targeting has shaped experiences of gender and generation. 


\section{Metropolitan Chicago}

Metropolitan Chicago is home to a diverse Muslim community of around 400,000, including African Americans, South Asians, Arabs, East Europeans, and a growing number of converts, and has some sixty mosques. Backlash for the $9 / 11$ attacks began almost immediately with verbal attacks on persons assumed to be Arab or Muslim, physical assaults, phone threats, and arson of Muslim institutions. In research conducted for a post 9/11 impact study funded by the Russell Sage Foundation, a majority of Arabs and Muslims in Chicago reported feeling that they were living in a state of siege for fully three years after the terrorist attacks of 2001.

Interviews with young, college-educated, middle-class ArabAmerican women, who are part of the larger study's sample, show that their lives were dramatically changed by the events of $9 / 11$. Shortly after the 9/11 attacks, one woman wearing a hijab was verbally assaulted when a woman in the car next to her shouted; "If I had a gun I'd shoot you now!" Other women reported their veils being ripped off their heads. Women who wear the hijab reported that "the stares, the refusal to look me in the face, and the verbal insults" persisted years after the attacks. Nearly all women interviewed, mulajilbant (veiled) or not, still say they fear for their safety when they are in places that lack ethnic diversity or areas that are all white. One Arab Muslim woman said, "You won't find me in a park or a forest preserve," while another said, "Soccer moms scare me the most." All agreed that Muslim women who wear the lijiab are the most vulnerable to assault in American society, because they are so easily spotted and targeted.

Feeling unsafe is not limited to the public sphere. The federal government's pattern of interrogations, arrests, home invasions, spying, and property confiscations appear random, unfocused, and discriminatory to members of the Arab and Muslim community. The government's use of secret evidence, closed hearings, eavesdropping on attorneys, and special registration of Arabs and South Asian Muslims have not built community confidence in the government, or in the claim that its only target is terrorists and people who support them. As a consequence, nearly everyone in the community feels vulnerable to a certain degree, even in their own homes. Consider that after the $9 / 11$ attacks, law enforcement authorities received 96,000 anonymous tips from persons reporting on Arab, South Asian, and Muslim neighbors. ${ }^{56}$

Post-9/11 racism has spilled over into the work site and in job 
discrimination against Muslims in Chicago as well. Some women report they are forced to listen to anti-Arab jokes and anti-Muslim comments at work. Others must face off-the-cuff remarks such as: "Is that a bomb in your briefcase?" A few women reported losing their closest work colleagues after $9 / 11$, when suddenly all Muslims were suspect. Many women say they are afraid to change jobs for fear that they will not find a new employer. Some report choosing to hide their Arab and Muslim identity on the job, posing as Greeks or Italians. There is no doubt that the hijab will prove to be a major barrier to employment and promotion for Muslim women.

"We are in a desperate situation. We were isolated from others and we need to build bridges," said one Chicago Muslim community leader. Post-9/11 formations within the Muslim community in Chicago reveal unprecedented pan-Islamic boundary crossing. This is perhaps best exemplified in Radio Islam, inaugurated in late 2004. Radio Islam's producers, researchers, and emcees span the range of African-American, Asian, Arab, African, and European Muslims. Their topics are similarly pan-Islamic and global. Pan-Islamic activities are also underway in civil rights organizing and defense, in the health care arena, among Muslim social workers, and in domestic violence prevention. The predominantly Arab Bridgeview mosque hosted Chinese American Muslim James Yee, the former Muslim chaplain at Guántanamo Bay who was falsely accused of espionage by the government. The case of now exonerated James Yee, and the efforts of his military colleagues at Guántanamo Bay to criminalize his actions, is a classic example of how profiling can transform everyday actions into supposed criminal behavior. Even greater boundary.crossing can be expected from the organized activities of second-generation Muslims, who are less constrained by affinities of culture and language than their immigrant parents.

Interfaith alliances also surfaced in Chicago during the post9/11 period as grassroots interfaith activists formed a protective circle around the Bridgeview mosque in the days after the $9 / 11$ attacks. Immigrant rights coalitions and civil rights groups strengthened their working relationships with Chicago's Arab, South Asian, and Muslim communities because of shared concerns over the goverument's policies. Together they protested the government's Special Registration program and deportations, assembling with banners at the federal building and offering support to registrees. Given their pre-9/11 experiences of subordi- 
nation and federal government profiling, Chicago's Arab community already had strong ties with National Lawyers Guild attorneys and progressive ethnic coalitions. These external alliances are particularly important since Arab, South Asian, and Muslim community resources have been redirected and extensively depleted after $9 / 11$ due to the financial demands of legal defense and civil rights work. There is less evidence, however, of the critical next step, when communities of Latinos, African Americans, Arabs, and South Asians would march together for their common interests. This type of solidarity requires another level of work that must emerge from within Arab, South Asian, African American and Latino grassroots community organizations and is complicated by class-based relationships between and among these groups.

The fault lines, as well as potential fluidity, of traditional Asian American organizing were widely evident after $9 / 11$, when the Chicago Commission on Human Relations Arab Affairs Commission took actions to represent Asian hate crime victims because the Asian Commission had not historically concerned itself with issues affecting South or West Asians. Similarly, Afghanis, Iranians, and Pakistanis who were called in for Special Registration in Chicago found no larger ethnic or geographically based organization to defend them. Fitting neatly into neither Arab nor Asian categories, as these two pan-ethnic groups have been traditionally defined and organized in the U.S., they found themselves without any representation to challenge their treatment. Post9/11 experiences have drawn these groups together, transcending traditional boundaries of race and geography, which they had no role in establishing.

\section{Boston}

In the aftermath of $9 / 11$, it became appa rent that Arab and South Asian Muslim youth in the U.S. were being dramatically forced to confront their belonging in the nation-state. This section focuses in particular on South Asian Muslim immigrant youth and draws on findings from an ethnographic study conducted in 2001-2003 of working-class, Indian, Pakistani, and Bangladeshi immigrant students in the public high school in Cambridge, Massachusetts and the impact of $9 / 11$ on their notions of cultural citizenship. ${ }^{57}$ The research also involved interviews with immigrant parents, school staff, community and religious leaders, city of ficials, and community activists. 
The Cambridge public high school has an extremely diverse student body that reflects the city's changing population, with students from Latin America, the Caribbean, Africa, and Asia. ${ }^{58}$ The South Asian immigrant student population is predominantly working- to lower-middle class and most work after school in part-time jobs in the service sector, such as fast food or retail. The majority of the Indian immigrant youth are from Sunni Muslim families, most from small towns or villages in Gujarat in Western India.

While local Muslim organizations or mosques in the Boston area draw a diverse Arab, North African, Asian, and African American population, the families of these working-class South Asian inmmigrant youth tend to socialize mainly with people from their own ethnic community. Furthermore, they generally do not affiliate with the Indian American or Pakistani American community organizations in the Boston area either, which tend to involve middle- to upper-middle class, suburban families. ${ }^{59}$ In some instances, class boundaries within South Asian American communities persisted and undermined community cohesiveness after $9 / 11$, and of ten those who truly were most vulnerable and could not afford legal counsel did not have the support of community organizations led by South Asian elites. The anti-Muslim and Hindu nationalist sentiment that has existed among segments of the Indian immigrant community as the Hindu Right has become a powerful movement in India, was one of the factors underlying the failure of many Indian American organizations to support or defend their Muslim compatriots, other than paying mere lip service. For example, the Indian Association of Greater Boston, the Pakistani Association of Greater Boston, as well as regional organizations representing the sizeable Gujarati community in the Boston area tended to serve middle- and upper-middle class families generally living in the suburbs. The Gujarati organizations were predominantly Hindu in membership and so did not include any of the Gujarati Muslim families in Cambridge. Given the massacre of Muslims in Gujarat in Spring 2002, religion is a highly charged issue within the Indian immigrant community. One of the Gujarati leaders interviewed for this study refused to comment on the inclusion of Muslims in his organization; other Indian community leaders were less defensive and some had even participated in marches for peace in South Asia during the military conflict on the Indo-Pakistani border and so presumably were more critical of communalism or nationalism in South Asia. However, in gen- 
eral, it was apparent that class cleavages and religious tensions embedded in homeland politics contributed to a sense of isolation for some South Asian Muslims and to a highlighting, rather than erosion, of fissures within some Indian American communities.

It is possible that the state's racial profiling of Muslims coinciding with anti-Muslim sentiments within South Asian communities could strengthen Muslim or pan-Islamic identity among the younger generation of South Asian immigrants, as happened for an earlier generation of South Asian Muslim youth in Britain. ${ }^{60}$ In their daily lives, South Asian immigrant youth do, in fact, hang out with Muslim African youth, especially, who are from Somalia, Ethiopia, or Egypt, forming an incipient pan-Islamic identity, but they also socialize with Latino, Caribbean, African American, and Asian students. For example, an Indian Muslim student, Ismail, argued for a more expansive conception of community: "I hang out with different kids. . I say if you want to live in a different world, you have to exist with them. . Sometimes you have to go outside [your group] and say, yeah, alright, we are friends too. . your relationship is gonna be bigger, right."

What was striking was the ways in which some South Asian Muslim youth seemed to go beyond simply expressing ideas of cultural difference and commonality, in a multiculturalist vein, to actually grapple with ideas about political and structural similarities others. Some of the students had gained a deeper understanding of their commonalities with African American youth as a result of their experiences with anti-Muslim racism, which they compared to anti-Black racism. Other South Asian immigrant youth, particularly the Muslim boys, felt targeted by other high school youth after $9 / 11$. Accusations of "you're a terrorist" or "you're a bin Laden" entered into what might otherwise be just an outbreak of youthful aggression among boys, perhaps, but had now become a part of a national discourse about Islan?. Yet, some of the boys, in particular, who had been targets of anti-Muslim incidents felt closer to the experiences of racial profiling endured by African Americans, as a result, and shared a critique of the U.S.'s racist policies toward people of color. One of the boys commented that, in his view, African Americans were not as shattered by the $9 / 11$ attacks on the U.S. because they feel alienated from the nation-state due to the legacy of slavery. While this racialized difference after $9 / 11$ is obviously more complex, what is important is that some youth believed that African Americans share their experience of marginalized cultural citizenship within 
the nation. While these young people are not involved in formal political organizations, they had a political analysis of the post$9 / 11$ climate that led to inter-racial affiliations.

In the Boston area, there were instances of formal alliances on an organizational level between Śouth Asian and Arab American communities and civil and immigrant rights organizations. For example, after $9 / 11$, members of the Massachusetts chapter of the American Arab Anti-Discrimination Committee, a national civil rights organization, as well as of the South Asian Committee on Human Rights, a grassroots group in the Boston area, participated in the New England Immigrant and Detainees Right Network, a coalition that included Asian American, Latino(a), and white immigrant and civil right activists and that organized around Special Registration, detention, and deportations. There were also joint activities focused on persecution of Arab, South Asian, and Muslim Americans organized by a loose network of Asian, Latino, Brazilian, and Haitian civil and immigrant rights groups. It is not clear yet what the long-lasting impact of these alliances will be, but these coalitions have raised important questions about secularism and civil rights, race and religion, and nationalism and class.

\section{Alliances}

One of the interesting things to note in the political rhetoric used by those discussing, and even protesting, the "racial profiling" of South Asian, Arab, and Muslim Americans is that the racial ambiguities of all three categories are generally not fully acknowledged in this discourse. Moustafa Bayoumi calls this the "tragic irony" of "racial profiling" after $9 / 11 .^{61}$ Muslim identity is not, technically, a racial category but in speaking of "anti-Muslim racism," for example, it is apparent that Muslim identity is treated as if it were a racial category by processes that are similar to those that comprise racial profiling in the U.S., for example, "flying while Muslim," referring to the profiling of Muslim and Arab passengers at airports and on airplanes, or "speaking out while Arab/Palestinian," referring to the censorship of pro-Palestine political speech. Race is, after all, a social and ideological construction and so the criminalization of Muslim Americans shows that Islam increasingly operates as a racial category in public discourse as well as practice.

Arabs and South Asians are both groups that have been ambiguously racialized in the U.S., variously classified as "white" and non-white at different moments. In 1923, the Supreme Court 
ruled that Bhagat Singh Thind, an Indian immigrant, was technically Caucasian but could not be considered white in the understanding of the "common man" and so was ineligible for citizenship. ${ }^{62}$ In general, Asian Americans have been positioned in various ways between the American racial polarity of black and white. As Gary Okihiro has observed, at some moments groups of Asian Americans have been considered "near black" and at others, "almost white."

Arabs were called "Syrians" when they first migrated to the U.S. in large numbers, around the turn of the twentieth century. Although officially considered "white," their eligibility for naturalization came into dispute in certain locations, especially in parts of the South and in northern industrial cities where they were union laborers. ${ }^{64}$ In a Southern case, the appellate court ruled in Dow $v$. The United States (1915) that "Syrians" were of the Semitic branch of the Caucasian race and thus eligible for U.S. citizenship. ${ }^{65}$ In Detroit, John Mohammed Ali argued before a U.S. District Court (1925) in a case that sought to revoke his naturalization (based on the Thind decision) that although he was born in India, he was Arabian, since his ancestors had originated in Arabia. The judge replied that Ali's ancestry was not at issue. He had dark skin and fit all the other criteria that defined the "common understanding" of non-white. Judges in Detroit and Buffalo consistently denied Arabs naturalization rights, without issuing written opinions that could be appealed. ${ }^{66}$ Many Arabs have rejected their official designation as Caucasian and white, because of their treatment in American society (a sentiment crystallized after 9/11), because Arabs comprise a range of phenotypes and cannot be contained by the concept of race, and because they basically disagree with organizing people by color. As long as they remain of ficially white, they are ineligible for the benefits that accrue to members of recognized minority groups and, more critically, they remain invisible to persons concerned with the status of minorities. ${ }^{67}$

While some had thought Arabs and Muslims were on the path to gaining cultural citizenship in the U.S., post-9/11 events changed all that. The questions nearly all have been asked, such as "where are you from?" and "are you a terrorist?," and comments telling them to "go back where you came from" revealed the borderlines between whiteness and otherness. The overwhelming consistency of responses in a post-9/11 study indicating that ArabAmericans feel least safe among whites shows that violent back- 
lash is a phenomenon associated by them with white America. The everyday cultural and social processes that accompany the state-driven "war on terror" construct Arabs and Muslims as not entitled to the same rights and privileges (i.e., cultural citizenship) that accrue to members of white society or "real" Americans, including the privilege against profiling and guilt by association. Federal government actions only serve to reinforce this idea. One often hears Muslims in Chicago remark that after the Oklahoma City bombings by Timothy McVeigh and his associates, neither all Christians nor all Irish became suspect citizens. The privileged are treated with individual precision, the non-privileged are profiled and punished collectively. However, since heightened U.S. nationalism and xenophobia have filtered into other immigrant and minority communities, some parts of these communities have absorbed anti-Arab racism and Islamophobia, making this a more complex and difficult issue. ${ }^{68}$

For many South Asian and Arab Americans, the post-9/11 backlash was a lesson in the ideological construction of race in the U.S. Some who believed that they would be shielded from racism because they were wealthy and inhabited predominantly white spaces found their "model minority" status stripped from them. It is important to show links between the social positioning of Arab and South Asian Americans to uncover the ways in which racial formation in the U.S. conjoins issues of material privilege, legal regulation, and state power. There are important alliances that need to be forged between these and other communities that would go beyond the confines of multiculturalist "difference" and build connections based on an analysis of political and material processes. For example, South Asian, Arab, and Muslim Americans who now have heightened concerns about issues of detention have much to learn from African Americans, Latinos, and Native Americans who have long fought against racismespecially that of the prison-industrial complex, and advocated for the rights of political prisoners. They have much to learn as well as from the historical experiences of Japanese Americans, who were incarcerated during World War II. The latter alliance was made more visibly than the first after $9 / 11$, through public statements of solidarity by Japanese American activists and documentary films that visually linked the experiences of both communities. Yet in order for there to be a deeper alliance between subordinated groups in the U.S., these symbolic alliances need to go beyond a politics of representation and address the 
historical impact of U.S. empire. Yet it is also true that responses by South Asian, Arab, and Muslim Americans themselves often remain within the realm of the symbolic and are enacted through protests that make visual and discursive statements, instead of ongoing political campaigns that challenge the very premise and goals of the state's profiling and link it larger imperial policies in the Middle East and South Asia.

\section{Conclusion}

The question of whether and how Arab Americans and South Asian Americans should work together, and how to define the relationship of Arab Americans to Asian Americans, raises two important issues mentioned at the beginning of this essay: the meaning of solidarity, and second, the role of boundaries. Solidarity, Vijay Prashad reminds us, is a desire that is actualized through a "tremendous act of production" for "unity is not waiting to happen." ${ }^{\prime 69}$ The identities that bind Asian Americans to Arab Americans need not be just of shared victimhood, but could be based in shared histories of contact and trade preceding Western hegemony, in common visions of liberation from colonialism, in collective memories of nationalist struggle, and in the alliances forged between newly independent Arab and South Asian nation-states by the non-aligned movement. ${ }^{70}$ It is in this political and epistemological spirit that we need to reconsider the boundaries between Asian American and Arab American studies. A strategically comparative approach rooted in a shared history and vision of solidarity, rejecting externally imposed divisions, would help keep in sight the political work of boundaries: academic, geographic, and cultural.

\section{Notes}

1. Some of the global impacts of the $9 / 11$ attacks and the War on Terror are discussed in a special issue of the Journal of Comparative Studies of Africa, Asin and the Middle East 24:1, Winter, Louise Cainkar, ed., "Global Impacts of the September 11 Attacks" (Durham: Duke University Press, 2004).

2. For example: Kathleen Benson and Philip M. Kayal, A Conmunity of Many Worlds: Arab Americans in Netw York City (New York: The Museum of the City of New York, 2002); RogerBurbach and Ben Clarke, September 11 and the U.S. War: Beyond the Curtain of Smoke (San Francisco: City Lights, 2002); Elaine Hagopian, ed., Civil Rights in Peril: The Targeting of Arabs and Muslims (Chicago: Haymarket Books, 2004); Jee Kim, et al., eds., Anolher World is Possible: Conversations in a Time of Terror (2nd ed.), (New Orleans: Subway and Elevated Press, 2002); Richard Leone and Greg Anrig, Jr., The War on our Freedoms: Civil Liberties in Age of Terrorism (New York: The Century 
Foundation, 2002); Bruce Lincoln, Holy Terrors: Thinking about Religion after Septeniber 11 (Chicago: University of Chicago Press, 2003); Stephen J. Schulhofer, The Enemy Within: Intelligence Gathering, Lnwv Enforcement, and Civil Liberties in the Wake of September 11 (New York: The Century Foundation, 2002); Sandra Silberstein, War of Words: Language, Politics, and 9/11 (New York: Routledge, 2002).

3. See, for e.g., Illegal to be Homeless: The Criminalization of Homelessness in the United Stafes (Washington D.C.: National Coalition for the Homeless, 2004).

4. See, for e.g., Michael Tonry, Malign Neglect: Race, Crime, and Punislument in America (New York: Oxford University Press, 1995).

5. T. H. Marshall, Citizenship and Social Class (Cambridge: Cambridge University Press, 1950).

6. Lauren Berlant, The Queen of America Goes to Washington City: Essays on Sex and Cilizenship (Durham: Duke University Press, 1997); Will Kymlicka, Multicultural Citizenslitp (Oxford, U.K.: Oxford University Press, 1995); John Hutnyk, Stephen Corry and Iris Jean-Klein vs. Richard Wilson and John Hutnyk, in The Right to Difference is a Fundamental Human Right, Peter Wade, ed., GDAT debate no. 10 (Manchester: Group for Debates in Anthropological Theory, University of Manchester, 2000).

7. Lok Siu, "Diasporic Cultural Citizenship: Chineseness and Belonging in Central America and Panama," Social Text 69, 19:4 (2001), 7-28; 9.

8. . Renato Rosaldo, "Cultural Citizenship, Inequality, and Multiculturalism," in Latino Cultural Citizenship: Claiming Identity, Space, and Rights, William. F. Flores and Rina Benmayor, eds. (Boston: Beacon Press, 1997); William F. Flores and Rina Benmayor, "Constructing Cultural Citizenship," in Lntino Cultural Citizenship: Claiming Identity, Space, and Rights, William F. Flores and Rina Benmayor, eds. (Boston: Beacon Press, 1997).

9. William F. Flores and Rina Benmayor, "Constructing Cultural Citizenship," in Latino Cultural Citizenship: Claiming Identity, Space, and Rights, William. F. Flores and Rina Benmayor, eds. (Boston: Beacon Press, 1997), 6.

10. Aihwa Ong, "Cultural Citizenship as Subject-Making," Current Anthropology 37:5 (December 1996): 737-762; 738. See also "Asians in the Americas: Transculturations and Power," Amerasia Journal 28:2, 2002.

11. Edward Said, Orientalism (New York: Vintage, 1978). See also “Orientalism and the Legacy of Edward Said," Amernsia Journal 31:1, 2005.

12. David Cole and James Dempsey, Terrorism and the Constitution: Sacrificing Civil Liberties in the Name of National Security (New York: The New Press, 2002), 168.

13. Gallup News Service, 8 August 2002.

14. October 28,2002 , reported by abcnews.com and found at http://www. religioustolerance.org.

15. Erik C. Nisbet and James Shanahan, Restrictions on Civil Liberties, Views of Islam, and Muslim Americans (Ithaca, N.Y.: Media and Society Research Group, Cornell University, 2004).

16. Vijay Prashad, "The Green Menace: McCarthyism After 9/11," The Sub- 
contintental: A Journal of South Asian American Political Identity 1:1 (2003): 65-75. See also, Louise Cainkar, "The Arab American Experience and the Social Construction of Difference" Journal of American Ethnic History. Twenty-Fifth Anniversary Issue. Inmigration, Incorporation, Integration, and Transnationalism: Interdisciplinary and International Perspectives 25:2 and 25:3, Winter-Spring.

17. There are volumes of material on this topic. See, e.g., chapters in Michael Suleiman, ed., Arabs in America: Building a New Fulure (Philadelphia: Temple University Press, 1999) and Elaine Hagopian, ed., Civil Rights in Peril (Ann Arbor: Pluto, 2004). For a summary, see Louise Cainkar "No Longer Invisible: Arab and Muslim Exclusion After September 11" Middle East Report, Fall, 224 (Washington D.C.: MERIP, 2002). http://www.merip. org/mer/mer224/224_cainkar.html.

18. The first known crackdown of this type was Operation Boulder, launched after the 1967 Israeli occupation of the remaining areas of Palestine, as well as of parts of Syria and Egypt. The FBI spied on Arab Americans and their organizations, interviewed their families, friends, neighbors and employers, and developed profiles of community activists. The 1987 "Los Angeles 8" (LA 8) case revealed another spying operation conducted by the government, when eight activists (seven Palestinians and a Kenyan) were arrested on charges of being "alien terrorists" in the service of the (now largely defunct) Popular Front for the Liberation of Palestine. The eight were taken from their homes in handcuffs and imprisoned under highsecurity conditions, but were eventually released by a judge for lack of evidence. In 2002, with still with noevidence that the LA 8 were linked to terrorist activities, the U.S. government re-opened the case under provisions of the USA Patriot Act, which shifted the burden of proof onto the defendants. Shortly after the LA 8 arrests, the Los Angeles Times uncovered an INS-FBI Contingency Plan to detain alien Arabs and Muslims in America en masse in a camp in Oakdale, Louisiana (Cole and Dempsey 2002, 35-48).

19. Louise Cainkar, "No Longer Invisible: Arab and Muslim Exclusion After September 11," Middle East Report 224, Fall (2002). http:/ / wiviv.merip.org/ mer/mer224/224_cainkar.html; Jordan Green, "Silencing Dissent," ColorLines 6:2 (2003), 17-20.

20. It can be safely assumed that at least 20,000 more Arabs and Muslims nationwide have been affected by one or more of the numerous post-9/11 national security initiatives.

21. See Fred Tsao and Rhoda Rae Gutierrez, Losing Ground (Chicago: Illinois Coalition for Immigrant and Refugee Rights, 2003) for a list of the thirty:seven initiatives, policy changes, and laws.

22. See, for e.g., Council on American-Islamic Relations, Guilt by Association (Washington D.C.: CAIR, 2003); United States Department of Justice, Office of Inspector General, The September 11 Detainees (Washington D.C.: GPO, 2003); American Arab Anti-Discrimination Committee, Report on Hate Crimes and Discrimination Against Arab Americans: The Post-September. 11 Backlash (September 11, 2001 to October 11, 2002), (Washington, D.C: ADC, 2002); Fred Tsao and Rhoda Rae Gutierrez, Losing Ground (Chicago: 
Illinois Coalition for Immigrant and Refugee Rights, 2003); Michael Isikoff "The FBI Says, Count the Mosques," Nerustreek, Feb. 3, 2002; Louise Cainkar, "No Longer Invisible: Arab and Muslim Exclusion After September 11" Middle Enst Report, Fall 224, (Washington D.C.: MERIP, 2002). http:// ivivw.merip.org/mer/mer224/224_cainkar.html.

23. David Cole and James Dempsey, Terrorism and the Constitution (New York: The New Press, 2002).

24. Ibid., 151.

25. The term "investigation dragnet" is used by the Council on American-Islamic Relations in Guilt by Association (Washington D.C.: CAIR, 2003).

26. United States Department of Justice, Office of Inspector General, The September 11 Detainees (Washington D.C.: GPO, 2003). See the film "Persons of Interest" (Icarus Films) for a view of these detentions from the perspective of detainees and their families.

27. CAIR, 2003. CAIR reports a decrease in discrimination complaints due to airline profiling and an increase in complaints referencing actions of the federal government.

28. See, for e.g., American Civil Liberties Union, Civil Liberties after 9/11: The ACLU Defends Freedon [A Historical perspective On Protecting Liberty In Times Of Crisis] (New York: American Civil Liberties Union, 2002); Ann Beeson and Ja meel Jaffer, Unpatriotic Acts: The FBI's Pouver to Rifle Through Your Personal Belongings Without Telling You (New York: American Civil Liberties Union, 2003); Seeking the Truth from Justice (New York: American Civil Liberties Union, 2003). Patriot Propaganda: The Justice Department's Camprign to Mislead the Public about the USA PATRIOT Act (New York: American Civil Liberties Union, 2003).

29. Patriot Propaganda, xi.

30. Ibid.

31. Paper presented at the Social Science Research Council and New York Times Journalists Training Institute; Fall 2004.

32. "Non-immigrant aliens" includes all immigrants who are inspected by the INS upon entry to the U.S. and are not U.S. citizens, permanent residents, applicants for permanent residency, or applicants for asylum. The rule for Special Registration excludes non-immigrants who are diplomats, persons working with international organizations, and a few other narrow categories of non-immigrants (categories $A$ and $G$ ).

33. INS Memo (undated) HQINS 70/28 from Johnny Williams, Executive Associate Commissioner, Office of Field Operations.

34. Carol Hallstrom, Department of Homeland Security, Community Relations, Chicago; June 2003. Also see Rachel Swarns, "More than 13,000 May Face Deportation," Newv York Times, June 6, 2003.

35. Carol Hallstrom, Department of Homeland Security, Community Relations, Chicago; June 2003.

36. Reuters, December 18,2002 . All persons placed in removal proceedings are permitted an administrative hearing. 
37. Reuters, December 18, 2002; BBC Neus Online, December 19, 2002; Nerusday, December 13, 2002.

38. Final numbers are not yet available from the Department of Homeland Security removal hearings. Some persons with valid applications for immigration benefits and close processing dates may have been allowed to stay. Operation Wetback is a glaring precedent to Special Registration. According to the University of Texas, Handbook of Texas: "It is difficult to estimate the number of illegal aliens forced to leave by the operation. The INS claimed as many as $1,300,000$, though the number of ficially apprehended did not come anywhere near this total. The INS estimate rested on the claim that most aliens, fearing apprehension by the government, had voluntarily repatriated themselves before and during the operation." www.tsha.utexas.edu/handbook/online/articles/OO/pqo1.html.

39. Persons out of status are thought to be 40 to 45 percent of the estimated eight million undocumented persons in the U.S. The rest are persons who "entered without inspection." Persons in the latter category are not subject to Special Registration; it is assumed to contain few Arabs and Muslims.

40. Michael Isikoff, "The FBI Says, Count the Mosques" Netwsicek, February 3, 2003. The initiative was announced in late January 2003.

41. House Judiciary Committee Report No. 97-264, October 2, 1981, "Need for Legislation." Immigration and Nationality Act Amendments of 1981, Pub. L. No. 97-116, 95 Stat. 1611 (1981).

42. Published in the Federal Register on August 12, 2002, as the "Final Rule on Registration and Monitoring of Certain Immigrants."

43. United States Department of Justice, Office of Inspector General, The September 11 Detainees (Washington D.C.: GPO, 2003); 105. 556 foreign nationals were deported during the Palmer Raids. See Alex Gourevitch "Detention Disorder" The American Prospect, January 31, 2003.

44. Council on American-Islamic Relations, The Status of Muslim Civil Rights in the United States: Stereotypes and Civil Liberties (Washington D.C.: CAIR 2002). "South Asian Leaders of Tomorrow, American Backlash: Terrorists Bring War Home in More Ways Than One" (Washington D.C.: CAIR 2001).

45. Mohamed Nimer, "Muslims in American After 9-11," Journal of Islamic Lawo and Culture 7:2, 2003.

46. Council on American-Islamic Relations, Guilt by Association (Washington D.C.: CAIR, 2003). Council on American-Islamic Relations, The Status of Muslim Civil Rights in the United States, 2004 (Washington D.C.: CAIR, 2004).

47. It is notable that the Chicago police were coding Arab victims under the category Asians and Pacific Islanders.

48. See Louise Cainkar, "Space and Place in the Metropolis: Arabs and Muslims Sceking Safety," in City and Society 17:2 (Berkeley: University of California Press, 2005).

49. See Cainkar, "Local Mosque Battles as Instantiations of Global Conflict" forthcoming.

50. Ibid. 
51. Louise Cainkar, "The Impact of $9 / 11$ on Muslims and Arabs in the United States," in John Tirman, ed., The Maze of Fear: Security and Migration After September 11 (New York: The New Press, 200-1), 215-239.

52. Arab American Institute Foundation, Profiling and Pride: Arab American Attitudes and Behavior Since September 11 (Washington D.C.: July 2002).

53. As'ad AbuKhalil, Bin Laden, Islam, and America's Nezv "War on Terrorism (New York: Seven Stories/Open Media, 2002), 29.

54. Mathew Lee, "U.S. Evangelist says Muslims 'Worse than Nazis,"' Agence France Press, November 12, 2002.

55. William Lind and Paul Weyrich, Why Islam is a Thrent to Ainerica and The West (Washington D.C.: Free Congress Foundation, 2002).

56. Cited in the aivard-svinning "Persons of Interest" (Icarus Films).

57. This research was supported by a grant from the Russell Sage Foundation.

58. The high school has approximately 2,000 students, of which about 40 percent are white and the rema ining 60 percent are students of color. African Americans are the largest group of students of color (about 25 percent), followed by Latino(a)s ( 15 percent), and Asian Americans (about 7 percent). In 2000-2002, 33 percent of students had a first language other than English and 14 percent were in the bilingual program, which suggests that the immigrant student population in the school is somewhere between these figures.

59. The 2000 Census reported 2,720 Indian immigrants (2.7 percent of the population), 125 Pakistanis, and 120 Bangladeshis in Cambridge, a city that is 68.1 percent White American, 11.9 percent African American, 11.9 percent Asian American, and 7.4 percent Latino (U.S. Census Bureau, 2000). This, of course, does not include undocumented immigrants. The "native" population is $\mathbf{7 4 . 1}$ percent and foreign-born is $\mathbf{2 5 . 9}$ percent; 17.7 percent are not citizens and 31.2 percent speak a language other than English. Cambridge is skewed by the presence of the academic community; while 8.2 percent $(3,108)$ of those enrolled in schools are in high school, fully 70.5 percent are in college or graduate school, and 38.5 percent of the population over tiventy-five years has a graduate or professional degree.

60. Jessica Jacobson, Islam in Transition: Religion and Identity annong British Pakistani Youth (London and New York: Routledge, 1998).

61. Moustafa Bayoumi, "How Does It Feel To Be a Problem?," Amerasia Jourunl 27:3/28:1 (2001/2002), 69-77; 73.

62. U.S. v. Thind, 261 US 20-4, 214-215 (1923). Joan Jensen, Passnge from Indin: Asian Indian Immigrants in North America (New Haven: Yale University Press, 1988).

63. Gary Okihiro, "Is Yellow Black or White?" in Margins and Mainstreants: Asinns in American History and Culture (Seattle: University of Washington Press, 1994), 31-63.

64. See Louise Cainkar, "Thinking Outside the Box: Arabs and Race in the U.S." in From Invisible Citizens to Visible Subjects: "Race" and Arab Americans Before and after September 11th, Amaney Jamal and Nadine Naber, eds. (Syracuse: Syracuse University Press, forthcoming). 
65. In the 1990s, nearly 100 years later, while blatant racially based legislation would be considered unconstitutional, legislative ef forts that effectively targeted some American ethnic groups more than others were on the increase. For Arab-Americans, the Anti-Terrorism Law is one such effort. On a social level; Arab-Americans increasingly report being treated as a people "different" from the white American core group (Naff, 1985).

66. INS, "Eligibility of Arabs to Naturalization," INS Monthly Review 1 (October 1943), 13.

67. See Louise Cainkar, "The Arab American Experience and the Social Construction of Difference" Journal of American Etlmic History. Truenty-Fifth Anniversary Issue. Immigralion, Inconporation, Integration, and Transnationalism: Interdisciplinary and International Perspectives 25:2 and 25:3 Winter-Spring.

68. Cainkar, forthcoming; Tram Nguyen, We Are All Suspects Nozv: Untold Stories from Immigrant Communities After 9/11 (Boston: Beacon Press, 2005).

69. Vijay Prashad, The Karma of Brown Folk (Minneapolis: University of Minnesota Press, 2000).

70. Cultural commonalities are useful and resonant in the emotional and aesthetic ties that bind people to one another, and there are certainly deep connections between Arab and South Asian Americans through language, religion, art, architecture, poetry, family ties, and social relationships, among so many other realms of culture. But as with Asian American pan-ethnicity, it is the historical traditions, tied to a shared political vision, that offer a more complex and critical basis for solidarity. Similar discussions and debates have occurred at different moments in Asian American studies about the relationship of Filipino Americans, Southeast Asian Americans, South Asian Americans, and Pacific Islanders to Asian American pan-ethnic identity, as Asian American studies has shifted away from its traditional preoccupation with Chinese American and Japanese American experiences. In rethinking the issue of margins and mainstreams in the field, it has been apparent that a politics of multiculturalist inclusion is not sufficient, without a rethinking of structural relations between center and periphery. The goals of a pan-ethnic project such as Asian American studies should not be to appropriate, subsume, or colonize other areas of study, but rather, as George Lipsitz points out, to focus "on objects of study that confound conventional modes of inquiry. Consequently, Asian American studies is not limited to the study of Asian Americans, but rather uses the specific historical experiences of Asian Americans to produce comparative studies of the role national cultures play in forming citizens" and to develop a "model of interethnic antiracism" (George Lipsitz, American Studies in a Montent of Danger, Minneapolis: University of Minnesota Press, 2001, . 123-124). 